\title{
Local responses to the European refugee crisis: Volunteering and the critique on humanitarianism
}

\author{
Author \\ Alina Neneh Reinhard \\ reinhardalina@gmail.com
}

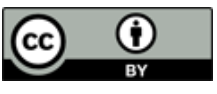

Received: $18 / 11 / 16$

Accepted: 22/11/16

Published: 30/11/16

\section{Resumen}

Desde el verano de 2015, una ola de compromiso voluntario con los refugiados se ha extendido por toda Europa. En este contexto, se han debatido las tensiones y preocupaciones en torno a la cuestión de la ayuda, el poder y la solidaridad. Este artículo contribuye a este debate centrándose en el voluntariado en el contexto de la llamada crisis europea de los refugiados.

Basado principalmente en observación participante y entrevistas informales, este estudio explora la necesidad de ayudar desde el punto de vista de los voluntarios y los diferentes actores en el seno de redes formales e informales emergentes. En particular, mi investigación tiene como objetivo comprender los complejos significados del voluntariado y su controvertido papel social.

Por un lado, a partir de datos recogidos durante varios meses de trabajo de campo en Berna, Suiza, este estudio examina las percepciones, expectativas y motivaciones de los voluntarios. Por otro lado, se centra en las negociaciones en curso sobre el papel del voluntariado, dentro de una red emergente de organizaciones humanitarias, instituciones religiosas, organizaciones comunitarias y voluntariado.

La crítica antropológica sobre el humanitarismo proporciona una base teórica para analizar las obligaciones morales percibidas por los voluntarios y los efectos de las relaciones resultantes. Recurriré a la teoría política para investigar arreglos urbanos emergentes vinculados al voluntariado en Berna. Sobre la base de mis conclusiones preliminares, propongo que es a través de las intervenciones humanitarias, como el voluntariado, que se puede atestiguar la posición actual de la sociedad civil y su potencial social y político.

Palabras clave: Voluntariado; migración; crítica al humanitarismo; obligación moral; nuevos arreglos urbanos.

\section{Abstract}

Since the summer of 2015 a wave of voluntary engagement with refugees has spread throughout Europe. In this context, tensions and concerns around the issue of help, power and solidarity have been debated. This article contributes to this debate by focusing on volunteering in the context of a so-called European refugee crisis.

Based mostly on participant observation and informal interviews, this study explores the need to help from the point of view of volunteers and different actors within 
emerging formal and informal networks. In particular, my research aims at understanding the complex meanings of volunteering and its contested social role.

On the one hand, based on data gathered during several months of fieldwork in Bern, Switzerland, this study examines volunteers' perceptions, expectations and motivations. On the other hand, it focuses on ongoing negotiations of the role of volunteering, within an emerging network of established aid organizations, faith-based institutions, community organizations and volunteers.

The anthropological critique on humanitarianism provides a theoretical basis for analyzing the moral obligations perceived by volunteers and the effects of the resulting relationships. Political theory will be employed in order to investigate emerging urban arrangements linked to volunteering in Bern. Based on my preliminary conclusions, I propose that by looking at humanitarian interventions, such as volunteering, the current position of civil society and its social and political potential can be demonstrated.

Keywords: Volunteering; migration; critique on humanitarianism; moral obligation; new urban arrangements.

Index

\section{Introduction}

2. Context of research

3. Theoretical backgrounds
4. Access and methodology

5. Ethnographic accounts

6. Summary and first preliminary conclusions

\section{Introduction}

In summer 2015, a widespread discussion took place about the thousands of refugees who had already lost their lives trying to cross the Mediterranean Sea. However, the discourse of an actual European refugee crisis only began to circulate in the media during the first week of September when the body of a 3year-old Syrian boy, Aylan Kurdi, was washed up on a tourist beach in Bodrum, Turkey and 71 refugees were found dead in a truck in Austria. In response to these events, many people travelled to the so-called Balkan Route to support refugees and to engage with the ongoing crisis. These globally mediatized incidents, among others, further provoked an extraordinary general meeting of European politicians in Brussels in September 2015. They came to an agreement to distribute 40,000 refugees within European countries. The very same week more than 50,000 people arrived in Austria. A few days later, Angela Merkel decided that the Dublin Agreement should no longer be enforced for Syrians within Germany. As a result of her decision, even if the refugees' fingerprints had first been registered in Hungary or Greece, the German authorities would not send them back there. The question of helping and the organization of help lies at the core of the debate among EU member states, and although Switzerland is not part of the Balkan Route, its negotiations on this issue are deeply influential in shaping its current political and public discourses. Migration is one of the key challenges of the twenty-first century and this article is about researching local responses to it. 


\section{Structure of the article}

In this first section, I introduce the focus of my research, my overall research question as well as the aim of the study. In the second section, I contextualize the research site and define what I mean by the notions of "volunteering" and "volunteer". The third section introduces the theoretical strands that run through this project. In the fourth section, I explain how I gained access to the research field and describe the methods used for collecting data. In the fifth section, I provide ethnographic accounts and first findings. Finally, I draw some preliminary conclusions from those findings.

\section{My motivation and research question}

In September 2015, I bought an Interrail ticket which took me first to Vienna, then to Budapest and the highly contested first border fence with Serbia. During this journey the voluntary engagement I witnessed left me confused but also opened my eyes. On the one hand, overwhelming numbers of volunteers were ready to "help" - and I even saw different NGOs and private initiatives competing. On the other hand, solidarity was decreasing, and there were even acts of hostility towards migrants. In this context, tensions and concerns around the issue of "helping" migrants were raised throughout Europe. Based on a combination of these personal experiences, academic readings and first evidence from the field I argue that volunteering plays an important role in local responses to the European refugee crisis. Therefore, I will analyze, discuss and explain the following research question: How shall we understand current forms of volunteering and the social role of volunteering today?

\section{Aim of the study}

In the general context of growing concerns around asylum issues, in which governments and civil society alike refer to a so-called "emergency", I am interested in understanding volunteering. A burgeoning body of scholarship has attempted to theorize different forms of humanitarian interventions, helping or demands for equality. Depending on the analytical perspective, they speak of the de- or post-politicization and (re-)politicization processes of such interventions. Against this background, this study aims at contributing to the ongoing debate on help, power, equality and solidarity.

\section{Context of research}

How asylum seekers are treated and where they live while going through the asylum process are of great importance to voluntary engagement. In the 1990s, Switzerland was confronted with larger numbers of asylum seekers than today. To meet the excessive demands created by the arrival of people from the former Yugoslavia, key areas of support have been professionalized. The reorganization of the asylum process in the 1990s went hand in hand with ongoing legal changes as well as spatial transformations. As a result of this process Switzerland now houses asylum seekers in temporary centres that are strictly separated from local communities both spatially and socially. According 
to a research project from the Swiss Forum for Migration and Population Studies (SFM) published in 2015 by Efionayi-Mäder et al., voluntary engagement has decreased massively since these changes. Civil society usually has no direct contact with the asylum seekers, and thus, according to the SFM, has less insight into and understanding of the whole procedure.

In October 2015, in a vibrant European context and in contrast to the spatial and social separation described above, a new asylum centre for 150 people opened in the very centre of the City of Bern, in Switzerland. During autumn 2015, local newspapers published such headlines as: Helpers are still waiting for their assignments, Volunteers are perceived as a distraction or People with Helper's Syndrome pose difficulties. These headlines exemplify the highly contested character of volunteering in the context of this crisis (Lettau 2015a, b, Probst 2016). On the one hand, volunteers would like to engage in different fields of action such as language, accommodation, work and integration. On the other hand, there is increasing professionalization of these procedures. My fieldwork started in this almost paradoxical situation.

\section{Defining volunteering}

My review of theories on volunteering reveals that many scholars use three criteria to define the notion of a volunteer: First, volunteers perform some task of their own free will; second, they receive no remuneration; and third, they act altruistically to benefit others (Mize Smith and Kramer, 2015: 2). Although I agree in general, I consider this straightforward definition somewhat problematic. Most of all because it precludes the debate in social science on the issue of providing help to migrants (Hess and Lebhuhn, 2014, MacKenzie et al., 2012) and the future role of civil society (Chandhoke, 2009; Kearns, 2012).

John Wilson defines volunteering more openly as any activity in which time is given freely to benefit another person, group, organization or cause (2000: 215). He admits that this definition clearly does not include that volunteers themselves benefit from their engagement in various ways, be it for their individual well-being, self-esteem or for educational and occupational achievement. Their engagement is not remunerated with a salary but they can receive rewards to cover expenses. Furthermore, this can be linked to different levels of commitment. Wilson reflects on definitional distinctions within existing theories on volunteering. One is the distinction between volunteers and social or political activists, which seems to be of relevance for my case. He highlights the fact that the roles of volunteer and of social activist are both social constructions (Wilson, 2000: 217). Often, as the anthropological debate on humanitarianism will further develop, volunteers want to "do good" or "to care about people" but do not claim political transformation. However, and as my findings show, volunteers quickly mobilize resources to speak to the public in order to demand political change. I agree with Wilson that there is no good reason to study volunteers and social activists separately; on the contrary it seems to be an interesting focus to treat this distinction as part of what we want to explain, rather than what we want to explain things with. The same can be said about the current debate on caring as a form of volunteering, in the sense of the former being a more person-to-person form of emotional labour. 
John Wilson points out that to date theorists have paid less attention to contextual effects on the decision to volunteer such as community or organizational characteristics, social ties or other regional or spatial specificities (2000: 229). First findings encouraged me to follow this direction with an open definition of volunteering as a starting point.

\section{Theoretical backgrounds}

In order to provide an overview of my theoretical backgrounds, I will proceed as follows: First, I will say something about the broader framework which lies behind this study. Second, I will introduce the anthropological critique on humanitarianism and how this debate affects my research question. Third, I briefly introduce a second theoretical strand, namely political theories on urban governance.

\section{Theoretical framework of the study}

Since the 1990s a transnational perspective on migration studies has led to the acknowledgement of the full complexity of migratory processes and the social construction of national categories. A variety of scholars, such as Nina Glick Schiller et al. (2006), have proposed that social scientists overcome this limiting, territorialized, national model, which they call "methodological nationalism" (Wimmer and Glick Schiller, 2002). They propose to analyze the effects and interdependencies for the whole population rather than for specific national categories such as migrants/non-migrants or citizens/non-citizens. In this sense my study tries to go beyond compartmentalizing, national categories by looking at a local response to current migratory processes on a city level. Nonetheless, I am aware that cities are part of nation-states as well of transnational social networks. Focusing on the local population, be they migrants or not, does not mean ignoring the state level. On the contrary, within contemporary urban dynamics it is important to examine the role of states within global restructuring processes and identify new ways through which states - together with other actors - shape particular localities (Glick Schiller and Çaglar, 2008).

These considerations motivated me to include anthropological critiques on humanitarianism as well as political theories on new forms of urban governance. Both pillars intersect in the issues revolving around current civic responses within the tropes of a so-called "crisis". The first dimension will provide the foundation for analyzing the moral obligations perceived by volunteers and the effects of the resulting relationships. The second dimension considers the transformation of the state itself as central for understanding the current position of civil society and, more precisely, the social role of volunteering.

\section{The anthropological critique on humanitarianism and volunteering}

As a social anthropologist I find myself maintaining a difficult and fraught balance between being critical of and yet accepting the principles of justice that drive such humanitarians as my research participants. In his book Humanitarian Reason (2012) Didier Fassin shows and analyzes how politics of compassion rely on emotions and moral sentiments and actions combining heart and 
reason. Current governments manage, regulate and support people through a logic of a morally defined humanitarian regime. This leads to asymmetries between the assisting and the assisted, the humanitarian and the victim, the active and the passive.

Miriam Ticktin (2006, 2011, 2014), among others, deconstructs notions underlying humanitarianism, such as the suffering victim, and reflects on the position of humanitarian workers. She contributes to the debate with her stronger focus on the collateral effects, such as the masking of structural inequalities and power relations go hand in hand with humanitarian interventions. She describes how humanitarian processes are anti-political in terms of not challenging established orders of inequality. Therefore, her focus is on the political dimension that constructs categories based on race and gender inequalities. In her work the issue of social and political change through humanitarian actions remains ambiguous. But she refers to the writings of Jacques Rancière and his idea of the "political" as disturbance or disruption of a given social order not as structure already in place (Ticktin, 2014: 283).

The anthropological critique on humanitarianism as described often focuses on international humanitarian interventions or humanitarian workers from established aid organizations such as the Red Cross, Médecins Sans Frontières or NGOs (Agier, 2008; De Lauri, 2015; Harrel-Bond, 2002; Malkki, 1996, 2015; Redfield, 2005). My case differs insofar as it looks at an emerging network of support in Switzerland, comprising mostly volunteers.

Based on these considerations, I argue that within the current debate on humanitarianism it is worth looking anew at the dynamics around the issue of helping, including the emergent meanings of the "political" in and around humanitarian spaces

\section{Reconsidering volunteering from political theory}

The writings of Rancière (2001, 2010), Žižek (1999, 2006) or Swyngedouw $(2010,2014)$ stress that contemporary cities are shaped by the development of new institutional and civic arrangements that include private and other non-state actors in the act of governing. Swyngedouw (2010) speaks of new regimes of urban governance. The state transfers responsibility to emerging regimes of urban governance that fuse together independent and interdependent actors from civil society, NGOs, local elites and experts.

Against a popular belief that these new forms of governance widen participation and politicize the population, the mentioned authors insist that these new selective associational networks mobilized by the state and to whom responsibility is devolved are representative of and constitute post-politics. In other words, what post-politics tends to prevent is the politicization and universalization of particular political demands. A vast apparatus of social workers or experts is mobilized, to reduce the overall complaint of a particular group to just this or that complaint or demand, with its own particular content (Žižek, 1999: 204). 
Therefore, I am interested in combining this perspective on de- or postpoliticization processes with the anthropological critiques on humanitarianism. I hope that the current position of civil society and its political potential can be exemplified by looking at humanitarian interventions, such as volunteering.

\section{Access and methodology}

My fieldwork in Bern started in November 2015 when there were already various support groups, namely churches, community centres and private volunteers in the planning stages. At information events the neighbourhood was informed about the asylum centre and the opportunities for volunteering there. Shortly after, volunteers organized community events such as welcoming dinners for those newly arrived. I participated at these events. Furthermore, I decided to visit the new German classes and I contacted many volunteers who were teaching German. Since December 2015, I have been participating as a volunteer at a drop-in for asylum seekers called Caffè Berna. There I made contact with Fuad, Aishe, Nalin and Chazi, a Syrian family. Our friendship resulted in further exchanges with other volunteers and a city-wide network, because the family is involved in nearly all of the centre's activities. Step by step I got in touch with many actors in the field and became part of the network.

My ethnographic fieldwork combines the collection of different sorts of data. I conducted participant observation throughout my fieldwork, most of all in the context of volunteering at Caffè Berna but also at public events, German classes and strategic meetings. My role as a volunteer at Caffè Berna allowed me to spend time at the facilities of the Evangelic-Methodist church and to come into contact with various volunteers. The network of existing and emerging support groups, established aid organizations, local faith-based organizations, the neighbourhood group, associations and private individuals had to organize many strategic meetings to coordinate their services and the volunteers. Since December 2015, I have participated in ten meetings and taken the minutes at seven of those. At these meetings I was more of a participant than a mere observer. I was often asked for information since I presented myself as a researcher and everyone knew that I was speaking to almost all of the supporting actors. Besides seeing these actors all around one table I also met them separately either by chance at various activities or at planned encounters in restaurants or in their homes. I thus learned about their individual expectations, conflicts and perceptions of what was going on (Breidenstein et al., 2015: 79). I also consulted local newspaper reports on the asylum centre and collected various forms of other reports. Furthermore, it is important to note that through spending much time with the Syrian family I gained yet another perspective, namely that of one who receives help. Although I use neither these conversations nor the great number of exchanges I have at Caffè Berna as data, they widened the angle on my research site. Beside participant observation I conducted two different sorts of interviews. In the context of volunteering, informal interviews took the form of conversational encounters without a definite structure (Breidenstein et al., 2015: 80). Additionally, I carried out several semi-structured interviews. This form seemed more appropriate for key actors at the administrative or political levels. A key aim of this long-term fieldwork is to track the organization of help and its consequences. 


\section{Ethnographic accounts}

The new asylum centre for 150 people opened in October 2015 in the very centre of the City of Bern, in Switzerland, in an old Fire Department building. Today more than 14 projects, including a restaurant, a boxing school, local markets, different workshops and youth work projects, are located here. The centre for asylum seekers is an integral part of this site. During information events about the centre, the number of people signing up as volunteers overwhelmed me. New support groups never form in a vacuum. MacKenzie et al. (2012), among others (Bromberg et al., 2007, Massey, 2004, 2005; Wren 2004), emphasize that cities in particular provide spaces in which to meet, organize and negotiate on solidarity, power and help at shared locations. According to these writings, public spaces and town centres can be crucial in providing the space needed to politicize. But, referring to Jacques Rancière's idea of the "political", I am still interested in whether or not volunteers become political.

\section{Motivations and expectations of volunteers}

Shortly after the opening of the asylum centre, many volunteers were quickly becoming impatient and frustrated because they could not all start at once. The centre's management admits that this volume of interest overextended their capacities in the first phase. Several of my research participants speak repeatedly about a veritable "boom" in the field of volunteering in Bern since the picture of the dead child, Aylan, was shared globally via the media. Many activities organized by volunteers, such as welcoming dinners, donations or drop-ins, are effectively based on urgency and people mention medialized discourses of "crisis" in relation to them. In this context I refer to Fassin (2012: 224), who highlights the fact that, against a popular view, humanitarianism is never separated from politics. The mere decision to help is a political one. Additionally, it also means selecting those that have priority or choosing the best way to represent the population assisted. In light of Jacques Rancières comments it is interesting to look at the different forms of support made available at the asylum centre and who the centre targeted as recipients of its assistance. In this initial phase, I talked to many volunteers who were providing various forms of activities for the newly arrived. Many of them refer to the current discourse of the European refugee crisis and want to contribute by "at least doing something". Various sorts of ad hoc reactions, donations of clothing or food or drop-ins, such as the Caffè Berna, emerged. There have been numerous activities organized for children and families in particular.

\section{Unintended consequences of volunteering}

Ticktin (2011: 20) rightly states that there are forms of moralism that arise in the urgency of the present but which are blind to the future. I listened to many volunteers who themselves criticized humanitarian interventions as generally alleviating the symptoms but only in the short term. Many of them volunteer as teachers and seem to treat this specific form of helping - teaching language skills - different from other forms of support. Formal German classes or 
informal lessons for the asylum seekers have quickly been organized. For example, many elderly volunteers have great expectations because volunteering gives them a new purpose at their stage in the life course. The coordinator of the German classes perceived this situation as follows:

"Volunteers see their work as meaningful. They are frustrated when people are late or lack discipline."

I talked to many volunteers teaching German who complained about exactly these issues. In some cases, the volunteers are explicitly blamed for expecting too much from the asylum seekers. A community organizer told me that they sometimes have to observe volunteers when they overstep the mark. Volunteering seems to offer some people the possibility to identify themselves with a new activity - volunteering in this sense means identification and also social belonging. I argue that the combination of moral and humanitarian obligations and personal expectations indeed reproduce asymmetrical relationships between the humanitarian and the "other" which I understand as unintended consequences of volunteering.

\section{New forms of social practices}

Additionally, as a result of informal social ties between volunteers and asylum seekers, new forms of social practices and living together emerge. For example, my data show that the number of asylum seekers attending activities organized by volunteers Most notably, with the support of volunteers, the asylum seekers organized a football team. Now many of them play in the local alternative league and are no longer interested in participating in volunteer-organized matches. At a strategic meeting in August 2016, ten months after the opening of the asylum centre, someone highlighted the fact that,

"The people now take part where they know people. Their informal contacts and networking with residents offered them the chance to take part in other settings in the city."

Initially accompanied by volunteers, many asylum seekers become familiar with the city in a social and spatial sense that goes beyond the neighbourhood. I became aware of this when I crossed paths with many of the asylum seekers while out shopping, at public festivities or in other public spaces. A young volunteer explained this development to me as follows: "it is a smooth transition from volunteering to friendship". Additionally, I learned that new forms of "working contracts" and of spending time or even living together arise from these social relationships. For example, several volunteers are very active in finding housing for the asylum seekers while they are consistently advised not to engage too much in this field.

\section{The emergence of new urban arrangements}

As I discovered, the association known as the Neighbourhood Group (Gruppe im Quartier, GiQ) was founded as much as one year before the arrival of the asylum seekers by people in the neighbourhood with a leftist background. Since November 2015 many strategic meetings have been organized in order to coordinate help, upcoming activities, public events and the large numbers of volunteers. Since I already knew many of the important 
actors, I came up with the idea of taking part at these meetings. I will shortly introduce the main actors present at these occasions alongside church representatives and coordinators of groups of volunteers.

On a state level, Salvation Army Refugees Aid (SAR) (Heilsarmee Flüchtlingshilfe, HAF) in Switzerland works independently of the international movement founded under the motto "Soup, Soap and Salvation" in the nineteenth century by the Christian Church. Providing accommodation and supervising asylum seekers, they work on behalf of the police and military as well as the health and welfare authorities of the Canton of Bern and employ 250 professional social workers. There are three important actors on the city level. First, the Coalition of Community Work in Bern (Vereinigung Berner Gemeinwesenarbeit, vbg) supports the participation of the population, strengthens the neighbourhood and the integration of its residents. Second, the Centre for Competence Integration (Kompetenzzentrum Integration, KI) leads the integration work of Bern city in three core areas: information and networking; advice and support; and integration through work. Third, the nearby schools take part in strategic meetings and stay in close contact with SAR.

Accompanying the emergence of this new network of relations among different formal and informal actors, I observed that the inclusion or exclusion of groups and individuals and their internal and external accountability of groups and individuals within this network occur in a non-transparent, ad hoc and situational manner. At strategic meetings, for example, some individuals simultaneously represent different institutions or groups depending on the composition of the meeting, that is, in terms of which other participants are present. Swyngedouw (2014) argues that such new constellations thus further rely on ill-defined responsibilities and ambiguous political objectives and priorities.

In 2014, the statutory financial support for German classes for asylum seekers was cancelled for economic reasons. SAR decided to actively recruit volunteers in order to be able to continue providing classes. In the case of the asylum centre in Bern many research participants speak of a "pilot project". For the first time an asylum centre only is operating only with volunteers in order to provide training in language skills. Swyngedouw (2010) and other authors (Beck, 1999; Žižek, 1999, 2006) state that the post-political condition is characterized by mechanisms that externalize state functions through privatization, professionalization and decentralization. My findings further illustrate the mobilization of resources through actors operating partially outside the state.

\section{Negotiations on the role of volunteering}

My findings also highlight that volunteer interference with administrative processes is a central theme in negotiation at meetings. Volunteers are sometimes openly accused of hindering administrative processes and obstructing the work of professional social workers. In the words of a city employee, 
"We don't need volunteer-advocates who come here and make demands.

The coordination of volunteers already means a lot of work."

This quote reveals the perception that confusion arises when individual volunteers find themselves in the role of personal advocates, for example when helping asylum seekers find accommodation or work. Meanwhile, the network frequently discusses at these meetings how to make use of all these volunteers. While taking the minutes at these strategic meetings, I tracked the development of ongoing negotiations between these actors, discussing city-wide strategies to better "manage" volunteering in order to both support and somewhat channel it. My data show the importance of the interdependence of volunteering and evolving social networks in Bern city. Promising equality, volunteers, more precisely specific coordinators of volunteers, come up with ideas and make demands within emerging urban arrangements. In this sense volunteering contributes to the production of new spaces of contestation. Žižek stresses that such arrangements share a high degree of consensus and trust that has been "built around the inevitability of neo-liberal capitalism as an economic system, parliamentary democracy as the political ideal, humanitarianism and inclusive cosmopolitanism as a moral foundation" (1999: 204). Conducting fieldwork at these occasions, I perceived a high degree of consensus shared within these new regimes of governance. For example, within a permanent discourse of "crisis", immediate help, the organization of support structures and ad hoc reactions are consistently discussed and even criticized but never the systemic, inherent inequalities of asylum procedures. Within the dynamics of these new arrangements of urban governance a big effort is made to coordinate all sorts of activities and support as well as to negotiate the future role of volunteering within this dynamic. To say it in the words of a SAR employee, volunteers are currently directed "into the right channels".

\section{Summary and first preliminary conclusions}

In this article, I have highlighted three elements which allow me to better understand volunteering. First, my definition of volunteering includes formal and informal modes of helping and includes caring or social and political activism. I prefer not to make too many of these kinds of distinctions because my findings show that in many cases a highly emotional and personal exchange, as well as friendship and political demands can emerge through volunteering. Second, the review of anthropological writings on humanitarianism offers me a framework of critical thinking about humanitarian governance which helps me to grasp what it means, how it works and what it hides. Third, reconsidering political theories provides me with a further framework to better understand the emergence and the meaning of new urban arrangements in the field of volunteering.

As Ticktin (2011: 223) stresses, "We all must think beyond care, beyond help, to forge a shared engagement", because humanitarian moralism itself is grounded in structural relations of inequality. My findings highlight that in order to understand the complex nature of volunteering, we have to examine if, how and by whom this "shared engagement" is being constructed and contested. My findings reveal that the motivation behind and the practice of volunteering are shaped by moral obligations grounded in humanitarian reason. Nonetheless, I assume that the critique on humanitarianism is not fully sufficient to explain volunteering, and, above all, its contested social role. While conducting 
fieldwork I observed the move towards new forms of urban arrangements and the ongoing negotiations on the future role of volunteering within this dynamic. I have shown that volunteering in Bern is shaped by this new regime of urban governance and the externalization of state functions. Therefore, I argue that volunteering as a humanitarian intervention can be better understood by also looking at the very symptoms of the post-political condition. Additionally, new forms of social practices, friendships and political demands emerge from the everyday practice of volunteering. I conclude that the combination of both theoretical strands allows a deeper insight into the ongoing negotiations about the position of civil society and the practices of volunteering including social and political activism.

\section{References}

Agier, Michel (2008). On the Margins of the World: The Refugee Experience Today. Cambridge: Polity.

Beck, Ulrich (1999). World Risk Society. Cambridge: Polity Press

Breidenstein, Georg, Stefan Hirschauer, Herbert Kalthoff and Boris Nieswand (2015): Ethnografie. Die Praxis der Feldforschung. UVK: Konstanz, Konstanz.

Breidenstein, Georg, Stefan Hirschauer, Herbert Kalthoff and Boris Nieswand (2015). Ethnografie. Die Praxis der Feldforschung. UVK: Konstanz, Konstanz.

Bromberg, Ava, Gregory D. Morrow and Deirdre Pfeiffer (2007). "Editorial Note: Why Spatial Justice?" Critical Planning, n 14: 1-6.

Chandhoke, Neera (2009). "Putting Civil Society in Its Place". Economic and Political Weekly, nº 44 (7): 12-16.

Efionayi-Mäder, Denise, Jasmine Truoung and Gianni D'Amato (2015). Wir können uns ein Abseitsstehen der Zivilgesellschaft nicht leisten. Zivilgesellschaftes Engagement im Flüchtlingswesen. Neuchâtel: SFM Studie 64.

De Lauri, Antonio (2015). The Politics of Humanitarianism: Power, Ideology and Aid. London: I.B. Tauris.

Fassin, Didier (2012). Humanitarian Reason. A Moral History of the Present. Berkeley: University of California Press.

Glick Schiller, Nina, Ayse Çaglar and Thaddeus C. Guldbrandsen (2006). "Beyond the Ethnic Lens: Locality, Globality, and Born-Again Incorporation". American Ethnologist, $\mathrm{n}^{\circ} 33$ (4): 612-633, DOI: 10.1525/ae.2006.33.4.612.

Glick Schiller, Nina and Ayse Çaglar (2008). "Migrant Incorporation and City Scale: Towards a Theory of Locality in Migration Studies". Willy Brandt Series of Working Papers in International Migration and Ethnic Relations, $\mathrm{n}^{\circ} 2$ (7): 1-35. 
Harrell-Bond, Barbara (2002). "Can Humanitarian Work with Refugees Be Humane?" Human Rights Quarterly, n² 24 (1): 51-85.

Hess, Sabine and Henrik Lebhuhn (2014). "Politiken der Bürgerschaft: Zur Forschungsdebatte um Migration, Stadt und citizenship". Suburban. Zeitschrift für kritische stadtforschung, $\mathrm{n}^{\circ} 2$ (3): 11-34.

Kearns, Ade (2012). "Mobility, Mixing, and Neighbourhood Change: A British Perspective". Cityscape, nº 14 (3): 185-188.

Lettau, Marc 2015a: Helfer im Asylbereich warten auf konkrete Aufgabe. Der Bund (30.12.2015)

http://www.derbund.ch/bern/kanton/helfer-im-asylbereich-warten-auf-konkreteaufgaben/story/21045153, 20.5.2016

Lettau, Marc (2015b). "Die Freiwilligen werden oft als Störfaktor empfunden". Der Bund (30.12.2015)

http://www.derbund.ch/bern/kanton/Die-Freiwilligen-werden-oft-als-Stoerfaktorempfunden/story/13834447, 20.5.2016.

MacKenzie, Robert, Chris Forde and Zinovijus Ciupijus (2012). "Networks of Support for New Migrant Communities: Institutional Goals versus Substantive Goals?" Urban Studies, nº 49 (3): 631-647, DOI: 10.1177/0042098011431620.

Malkki, Liisa H. (1996). "Speechless Emissaries: Refugees, Humanitarianism, and Dehistoricization". Cultural Anthropology, n 11 (3): 377-404.

Malkki, Liisa H. (2015). The Need to Help. Durham, NC: Duke University Press.

Massey, Doreen (2004). "Geographies of Responsibility". Geografiska Annaler, $\mathrm{n}^{\circ} 81$ (1): 5-18.

Massey, Doreen (2005). For Space. London, California: SAGE.

Mize Smith, Jennifer and Michael W. Kramer (2015). Case Studies of Nonprofit Organizations and Volunteers. New York: Peter Lang Publishing.

Probst, Lucia (2016). "Schwierig sind Leute mit Helfersyndrom". Berner Zeitung (04.02.2016)

http://www.bernerzeitung.ch/region/bern/schwierig-sind-leute-mithelfersyndrom/story/13794239, 20.5.2016.

Rancière, Jacques (2001). "Ten Theses on Politics". Theory \& Event, n 5 (3).

Rancière, Jacques (2010). Dissensus: On Politics and Aesthetics. London: Continuum Int.

Redfield, Peter (2005). "Doctors, Borders, and Life in Crisis". Cultural Anthropology, $\mathrm{n}^{\circ} 20$ (3): 328-361. 
Swyngedouw, Erik (2010). "Post-Democratic Cities. For Whom and for What?" Paper Presented at the Concluding Session of the Regional Studies Association Annual Conference. Budapest.

Swyngedouw, Erik (2014). "Let the People Govern? Civil Society and Governmentality and Governance-Beyond-the-State". Urban Studies: 1-50.

Ticktin, Miriam Iris (2006). "Where Ethics and Politics Meet: The Violence of Humanitarianism in France". American Ethnologist, n 33 (1): 33-94.

Ticktin, Miriam Iris (2011). Casualties of Care: Immigration and the Politics of Humanitarianism in France. Berkeley: University of California Press.

Ticktin, Miriam Iris (2014). "Transnational Humanitarianism". The Annual Review of Anthropology (43): 273-289.

Wilson, John (2000). "Volunteering". Annual Review of Sociology (26): 215240.

Wimmer, Andreas and Nina Glick Schiller (2002). "Methodological Nationalism and Beyond: Nation-State Building, Migration and the Social Sciences". Global Networks, $\mathrm{n}^{\circ} 2$ (4): 301-334.

Wren, Karen (2004). Building Bridges: Local Responses to Resettlement of Asylum Seekers in Glasgow. Glasgow: Scottish Centre for Research on Social Justice.

Žižek, Slavoj (1999). The Ticklish Subject - The Absent Centre of Political Ontology. London: Verso.

Žižek, Slavoj (2006). The Parallax View. Cambridge, MA: MIT Press. 